\title{
The Dividing Line Between Shareholder Democracy and Board Autonomy: Inherent Conflicts of Interest as Normative Criterion
}

by

SOFIe CoOLs*

In the past decades, shareholder democracy has been the center of attention in corporate governance research. Academic commentators have lined up on both sides of the debate and have fiercely advocated either increasing or limiting shareholder power. Yet, the scope of many of these arguments has so far been unclear, so that they could in fact always be used again for even more, or even less, shareholder democracy, until the board or the shareholder meeting is entirely depleted of authority. This article explores the dividing line between sharebolder say and board autonomy in public companies and puts forward a normative criterion that can be consistently applied to the various subject matters of corporate decision-making. A criterion based on "inherent" conflicts of interest of directors, I argue, is economically efficient and meets the underlying rationale of existing corporate law systems in Europe and the United States. Specifically, shareholder power should comprise, but also be limited to, matters in which directors face an inherent conflict of interest. The problems of sharebolder passivity, short-termism and empty voting and the concern about stakeholder interests do not call for a further reduction of shareholder power beyond this limitation.

Table of Contents

ECFR 2014, 258-296

I. Introduction . . . . . . . . . . . . . . . . . . . . . . . . . . . . . . . 259

II. Lack of a consistent normative criterion . . . . . . . . . . . . . . . . 260

1. Historical and intellectual basis of the existing power allocation . . . . 261

2. The current academic debate on shareholder say . . . . . . . . . . 266

III. An economically efficient criterion for allocating corporate power . . . . . 269

1. An integrated view on transaction costs and agency costs . . . . . . . 270

2. Cost comparison of board and shareholder meeting . . . . . . . . . 272

3. Conflicts of interest as normative criterion . . . . . . . . . . . . 273

4. Difference with conflict of interest procedures and related party trans-

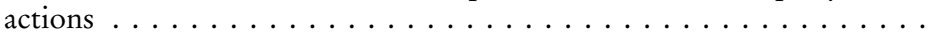

* S.J.D. Candidate Harvard Law School; affiliated researcher University of Leuven. Earlier drafts of this article, entitled "Defining the Optimal Scope of Decision-Making Authority of the Shareholders Meeting”, were presented at a workshop at ETH Zurich and at the annual symposium of the European Company and Financial Law Review held in Milan on September 27, 2013. I would like to thank Professors Koen Geens, JeanMarie Nelissen Grade and Marieke Wyckaert for their helpful comments. 
5. A brief application . . . . . . . . . . . . . . . 279

IV. Counterarguments and refinements . . . . . . . . . . . . . . 282

1. Market discipline and legal agency strategies . . . . . . . . . . . 282

2. Dysfunctional shareholders: shareholder passivity, short-termism, private interests, institutional investors and proxy advisors . . . . . . . 286

3. Tunneling by controlling shareholders . . . . . . . . . . . . . . 29 290;

4. Stakeholder interests . . . . . . . . . . . . . . . . . 293

V. Conclusion . . . . . . . . . . . . . . . . . . . . . . . . . . . 296

\section{Introduction}

The distribution of corporate power between the shareholder meeting and the board of directors is both highly topical and as old as the corporation itself. Since the origins of the stock corporation, lawmakers have been preoccupied with striking the right balance. Judging from the heated discussions on shareholder democracy today, both in legal scholarship and at the legislative level, the matter still has not reached equilibrium. As if that were not enough, the division of powers between boards and shareholder meetings is gaining importance on the European continent, as stock ownership patterns slowly seem to become more dispersed, in which case fewer boards will be dominated by controlling shareholders.

The current state of affairs is the result of a historical evolution in which legislators were concerned about economic efficiency but did not, until recently, dispose of adequate economic frameworks. In the absence of such frameworks, lawmakers sought inspiration in the prevalent conception of the corporation, theories of legal personality and analogies to a parliamentary democracy. This led to less than optimal choices, which repeatedly had to be corrected later on. Modern problems, such as empty voting and agency conflicts within institutional investors, have further complicated the issue and, as will be seen, have sometimes unnecessarily diverted attention away from the essential function of shareholder democracy.

Today, solid economic frameworks are available that allow the development of a consistent normative criterion for an efficient allocation of powers. Building on the concepts of both agency costs and transaction costs, this article advances a criterion based on conflicts of interest that are inherent to the position of directors (sometimes combined with a materiality requirement). Inherent conflicts of interest are different from those tackled by rules on related party transactions and conflict of interest procedures, in that they do not depend on concrete circumstances, but can be expected to arise systematically. Nevertheless, the conflicts of interest procedure and rules on related party trans- 
actions exhibit the same underlying rationale as the proposed criterion and, as such, support its validity.

This article is organized as follows. Part I identifies the factors that have shaped the allocation of corporate powers throughout history and those that play a role in the current academic debate. It exposes the need for a consistent normative criterion, which is developed in Part II. Based on a comparison of the board of directors and the shareholder meeting with regard to both agency costs and transaction costs, Part II proposes, delineates and briefly applies the criterion of inherent conflicts of interest. Part III analyzes and demonstrates the weakness of many of the arguments commonly invoked against shareholder power, at least in legal systems that apply the proposed criterion.

For the ease of exposition, Parts I and II will assume that the corporate interest equals long-term shareholder value. This assumption will be relaxed in Part III, Section 4, which investigates if concerns about stakeholder interests affect the proposed criterion. It should also be noted that the scope of this article is restricted to the internal distribution of decision-making authority, as provided by the law, for public companies that are not part of a group. No consideration will be given to the questions of how much the parties can deviate in the articles of association, how the proposed criterion must be adapted in order to function in private companies, or whether specific group law is desirable. Neither does the article enter into the division of powers between directors and managers (who will be considered as acting together) or the choice between the many forms and shades of decision-making authority (such as prior authorization, ex post ratification etc.).

\section{Lack of a consistent normative criterion}

The distribution of powers between directors and shareholders has almost constantly been in motion, with legislators alternately strengthening the shareholder meeting and the board of directors. The first Section of this first Part shows how these developments concurred with developments in the conception of the corporation and in the theory of legal personality ${ }^{1}$ and how they have also been inspired by the analogy between corporate decision-making and political decision-making in a parliamentary democracy, and, in the end, finds this historical basis wanting. The second Section outlines the rich academic debate on the subject and highlights the need for a clear

1 About the distinction between theories of legal personality and theories of the corporation, see Nicholas H.D. Foster, Company Law Theory in Comparative Perspective: England and France, 48 Ам. J. Сомp. L. 573, 580 (2000). 
criterion for the allocation of powers between the board and the shareholder meeting.

\section{Historical and intellectual basis of the existing power allocation}

At the inception of the stock corporation, in the form of the chartered East India Companies of the early seventeenth century, shareholder power was severely limited because corporations were considered a state affair. ${ }^{2}$ This would gradually change over the eighteenth century. In the nineteenth century, the stock corporation emerged in the new corporate laws of several European jurisdictions. ${ }^{3}$ By then, the shareholder meeting was considered the supreme corporate body with absolute power. ${ }^{4}$ Much of this was through practice more so than black letter law. Both the French Commercial Code of 1807 and the Prussian Stock Corporations Act of 1843 were silent as to the organization of corporate decision-making. ${ }^{5}$ The French Commercial Code did not even mention the shareholder meeting and confined itself to stipulating that directors were to be appointed temporarily and were removable from office. ${ }^{6}$ By virtue of civil law principles, however, a director's mandate for governing a company, no matter how broad the mandate was formulated in the articles of association, excluded the ability to dispose of corporate property. ${ }^{7}$ In addition, the government frequently steered towards an expansion of the competences of the shareholder meeting in its review of all deeds of incorporation and charter amendments. ${ }^{8}$ Across the water, a commensurate norm of shareholder primacy was prevailing in the American jurisprudence and case law until the beginning of the twentieth century. ${ }^{9}$

2 Alexander Schall, Corporate Governance after the Death of the King - the Origins of the Separation of Powers in Companies, 8 ECFR 476, 478-80 (2011).

3 Sofie Cools, Europe's Ius Commune on Director Revocability, 8 ECFR 199, 223-29 (2011).

4 Sabrina Bruno, Directors' Versus Shareholders' Primacy in U.S. Corporations Through the Eyes of History: Is Directors' Power 'Inherent'?, 9 ECFR 421, 434-36 (2012) (discussing the French Commercial Code and the English Joint Stock Companies Act, which have subsequently been used as a model by many other jurisdictions).

5 With regard to the Prussian statute: Holger Fleischer, Kompetenzen der Hauptversammlung - eine rechtsgeschichtliche, rechtsdogmatische und rechtsvergleichende Bestandsaufnabme, in 2 Aktienrecht im Wandel 430, 432 (Walter Bayer \& Mathias Habersack eds., 2007). With regard to the French Code, see next footnote.

6 Art. 31 Code de Commerce of 1807. See also art. 44 and 46 Code de Commerce of 1807.

7 Application of art. 1988 Code Civil pursuant to art. 18 Code de Commerce.

8 René Piret, L'Évolution de la législation belge sur les Sociétés anonymes 29 (1946). See also Yves De Cordt, L'Égalité entre actionnaires 189 (2004).

9 Bruno, supra note 4, at 431-34. 
At the root of the choice for a strong shareholder meeting lay a deep mistrust of directors, ${ }^{10}$ understandable in a context where many of the current mechanisms to hold directors accountable were still missing. As Adam Smith famously warned, directors might not be vigilant in dealing with "other people's money". ${ }^{11}$ Shareholders were seen as owners, a view deemed in line with the fictitious theory of legal personality. ${ }^{12}$ Shareholder primacy also fit snugly into the contractual theory of the corporation, which dominated French legal thinking during the nineteenth and beginning of the twentieth century ${ }^{13}$ and was explicitly adhered in the French Civil and Commercial Codes. ${ }^{14}$ Under this theory, the corporation is a contract between shareholders and is governed by contract law. ${ }^{15}$ Accordingly, the wills of the individual shareholders are determinative in corporate decision-making and there was no role for a separate, superior corporate interest. ${ }^{16}$ The shareholder meeting was, therefore, logically the highest and most powerful corporate body. ${ }^{17}$ In the contractual conception of the corporation, directors were qualified as agents (in the legal meaning of the word) ${ }^{18}$ a term explicitly used in the French Commercial Code. ${ }^{19}$ An important source of inspiration in designing the relationship between shareholders and directors was, therefore, agency law, which provided the basis for at will removability of directors. ${ }^{20}$ In addition, the legislator consciously copied elements from the political structure of a parliamentary democracy. ${ }^{21}$

10 The fear was more specifically that founders would sell overvalued shares, grant themselves lifelong mandates as directors and take private benefits (Anne Lefebvre-Teillard, L'intervention de l'Etat dans la constitution des sociétés anonymes (1807-1867), RHDFE 383, 405-06 (1981); Henri LÉvy-Bruhl, Histoire juridique des Sociétés de COMmerce en France aux XVIIe et XVIIIe siècles 52 (1938); Piret, supra note 8, at 35).

11 Adam Smith, An Inquiry into the Nature and the Causes of the Wealth of Nations 700 (Modern Library, 1937) (1776).

12 Bruno, supra note 4, at 436-37.

13 Foster, supra note 1, at 589; Jacques Malherbe et al., Droit des sociétés. Précis 206 (2011); Philippe Merle, Sociétés commerciales 42 (2012); T. Tilquin \& V. SimoNART, 1 TRAITÉ DES SOCIÉTÉs 95, 99 (1996).

14 Art. 13 Code Civil of 1804; art. 18 Code de Commerce of 1807.

15 Merle, supra note 13, at 42; Tilquin \& Simonart, supra note 13, at 99.

16 De Cordt, supra note 8, at 215; Malherbe et al., supra note 13, at 206.

17 Martin Gelter, Taming or Protecting the Modern Corporation? Shareholder-Stakeholder Debates in a Comparative Light, 7 NYU J. L. \& Bus. 641, 665, 667 (2011); J. VAn Ryn, 1 PRINCIPES DE DROIT COMMERCIAL 320 (1954).

18 Morton J. Horwitz, Santa Clara Revisited: The Development of Corporate Theory, 88 W. VA. L. Rev. 173, 183, 215-216 (1985-86); Tilquin \& SimonarT, supra note 13, at 100.

19 Art. 31 Code de Commerce of 1807.

20 Art. 2004 Code Civil of 1804.

21 Preparation of the first Belgian corporate law of 1873: Pirmez Report to the Chamber of November 14, 1868, in Guillery, Commentaire législatif, III, 209, No. 7 (“les sociétés anonymes sont une espèce de petit gouvernement. Le système de notre Constitu- 
At the onset of the twentieth century, boards started to take on a larger role in practice than the above account would seem to suggest, as shareholder meetings were plagued by apathy, absenteeism and shareholder incompetence..$^{22}$ Once unfaltering, confidence in shareholder meetings eroded quickly, and European legislators and Anglo-Saxon courts, increasingly concerned about economic efficiency, started attributing more authority to the board of directors. ${ }^{23}$ During the twentieth century a growing aspiration to protect minority shareholders from expropriation contributed to this evolution. ${ }^{24}$ Two-tier boards were introduced (most notably in Germany and the Netherlands) to reduce the board's dependence on controlling shareholders and were used to allow employee participation. ${ }^{25}$ In the ambitious harmonization program of the newly established European Community, the European legislator followed suit with similar structures in the (then still) proposed Statute for a European Company and in the draft Fifth Directive. ${ }^{26}$ National laws implementing the First Directive assigned boards of directors general power to represent the company. ${ }^{27}$

The conception of the corporation evolved simultaneously with the changing role of the board of directors. The contractual view gave way to the institutional view, which began to appear halfway into the nineteenth century. ${ }^{28}$ According to the institutional theory, the corporation is a long-standing structure that is governed by a set of rules the parties cannot modify and which furthers a common corporate interest over the individual interests of the shareholders. ${ }^{29}$ The authority of the corporate bodies under the theory no longer emanates from an agreement, with the possibility for the shareholder meeting to delegate authority to the directors, but from the law. Powers are distributed hierarchically in function of the corporate interest ${ }^{30}$ and tend to be allocated

tion, dont nous nous trouvons fort bien, est un régime de grande liberté et de grande publicité; nous proposons de l'appliquer aux sociétés anonymes"). The same was true for the French Conseil d'Etat: DE CORDT, supra note 8, at 188-90.

22 Léon Rycx, 1 Traité juridique et pratique des societies anonymes 220 (1913); VAN RYN, supra note 17, at 392.

23 FLEISCHER, supra note 5, at 435; Bruno, supra note 4, at 437-43.

24 Dalia Tsuk Mitchell, Shareholders as Proxies: The Contours of Shareholder Democracy, 63 Wash. \& Lee L. Rev. 1503, 1512-13, 1554-60 (2006).

25 See Klaus J. Hopt, The German Two-Tier Board: Experience, Theories, Reforms, in Comparative Corporate Governance 227 (Klaus J. Hopt et al. eds., 1998).

26 Art. 73, 137 draft SE Regulation; art. 2 first draft Fifth Directive.

27 Art. 9 First Directive.

28 Isabelle Corbisier, La sociétÉ: CONTRAT ou institution? 224-226 (2011) (France).

29 EMile Gaillard, LA THÉORIE INSTITUTIONNELLE ET LE FONCTIONNEMENT DE LA SOCiÉté anonyme 37-43 (1932); Maurice Hauriou, Précis élémentaire de droit administratif 26 (1943); VAN RYN, supra note 17, at 205-07.

30 De CORDT, supra note 8, at 216; GAILlARD, supra note 29, at 39-40. 
generously to the board of directors. ${ }^{31}$ The directors are no longer qualified as agents, but as (members of) corporate organs with independent authority. ${ }^{32}$ The stronger position of the board is thus also connected with the organic theory and, more generally, the conception of the legal personhood as a real entity. ${ }^{33}$

Towards the end of the twentieth century, the pendulum swung again in the direction of increased shareholder power, albeit less pronounced in the United States. ${ }^{34}$ The early European harmonization efforts of the 1970s and the 1980s, especially the Second Directive (on capital) and the Third and Sixth Directives (on domestic mergers and divisions) respectively, had already modestly confirmed and sometimes expanded shareholder authority. ${ }^{35}$ The proposed Fifth Directive contained several provisions on the internal distribution of powers, ${ }^{36}$ but was abandoned after long and difficult negotiations. ${ }^{37}$ It is in the 1990s, after the takeover wave of the 1980s, that the tide turned in favor of the shareholder meeting and democratic discourse proliferated once again. At the turn of the millennium, European corporate law enjoyed a revival and joined in. The Commission's Action Plan of $2003^{38}$ emphasized the need for improved shareholder democracy, but efforts focused on the one share one vote rule and, more successfully, procedural shareholder rights, ${ }^{39}$ rather than on expanding or consolidating the substantive powers of the general meeting. A remarkable exception was the planned Takeover Directive, in which shareholder say was a main theme. ${ }^{40}$ However, the proposed rule imposing board passivity during takeovers turned out too revolutionary and was rendered optional in de directive eventually enacted in 2004. ${ }^{41}$ Inefficiencies and abuses brought to light by the financial crisis of 2007-08 fueled the demand for more shareholder say, especially on director and executive compensation. The European Commission responded with several recommendations ${ }^{42}$ and a second Action Plan,

31 Gelter, supra note 17, at 665, 667.

32 Merle, supra note 13, at 43; Tilquin \& Simonart, supra note 13, at 108; VAn Ryn, supra note 17 , at 320 . Not all institutionalists welcome the organic theory though (Corbisier, supra note 28, at 171-72, 185).

33 Bruno, supra note 4, at 438-39; Horwitz, supra note 18, at 183.

34 Mitchell, supra note 24, at 1514, 1572.

35 FLEISCHER, supra note 5, at 442-44.

36 See art. 37, 48, 50, 55 first draft Fifth Directive, 1972 O.J. (C 131) 49.

37 Withdrawal of obsolete Commission proposals, 2004 O.J. (C 5) 2.

38 Commission Communication of May 21, 2003, Modernising Company Law and Enhancing Corporate Governance in the European Union - A Plan to Move Forward, Brussels, COM(2003) 284.

39 E.g. Shareholder Rights Directive 2007/36/EC, 2007 O.J. (L 184) 17.

40 See art. 3 Takeover Directive.

41 Cons. 13 \& art. 9 jo. 12 Takeover Directive.

42 Commission Recommendation 2004/913/EC fostering appropriate regime for remu- 
dated December 12, 2012, ${ }^{43}$ in which it considers imposing a shareholder vote on director remuneration policies and providing shareholders with better control over related party transactions. ${ }^{44}$ Since the financial crisis several shareholder empowerment efforts have also finally come to fruition in the United States, with the enactment of the Dodd-Frank Act and with corporations massively moving away from staggered boards and plurality voting in director elections. ${ }^{45}$

Throughout history, lawmakers have increasingly been concerned about the economic efficiency of corporate decision-making. Since they did not, until recently, dispose of analytical frameworks, let alone reliable empirical evidence, they sought inspiration in politics and theories of the corporation, which led them to constitutional law and contract law. Yet, these form only a slender basis that does not support building a framework for an efficient allocation of corporate power. The contractual and institutional views of the corporation, and even compromises between both, serve well as a general descriptive framework only and do not provide clear enough reference points to play a role at the normative level. ${ }^{46}$ Similarly, the comparison of corporate decision-making with a parliamentary democracy can yield refreshing insights and serve as a source of inspiration, but does not give any guidance on how to allocate concrete powers between corporate bodies. More importantly, however, a parliamentary democracy differs from corporate decision-making in so many key respects that caution is warranted when drawing any analogy between both: a parliamentary democracy is an indirect form of democracy, whereas shareholders do vote directly; voting rights are allocated per share in corporations and per citizen in a state; shareholders can freely join and leave the company by purchasing and selling stock, while leaving is seldom an option for citizens; unless one adheres a rigid contractual view of the corporation, shareholders are not the ultimate

neration of directors of listed companies; Commission Recommendation 2009/384 on remuneration policies in the financial services sector; Commission Recommendation 2009/385 complementing Recommendations 2004/913/EC and 2005/162/EC as regards the regime for the remuneration of directors of listed companies.

43 Commission Communication of December 12, 2012, Action Plan: European company law and corporate governance - a modern legal framework for more engaged shareholders and sustainable companies, $\operatorname{COM}(2012) 740$.

44 Ibid., 10-11. See also European Parliament resolution of March 29, 2012 on a corporate governance framework for European companies; Statement of the European Corporate Governance Forum on Related Party Transactions for Listed Entities, March 10, 2011; Commission Green Paper 2011 - The EU corporate governance framework; Statement of the European Corporate Governance Forum on Director Remuneration; March 23, 2009.

45 Gelter, supra note 17, at 651-58; Marco Ventoruzzo, Empowering Shareholders in Directors' Elections: A Revolution in the Making, 8 ECFR 105, 109-110 (2011).

46 See De CoRdT, supra note 8, at 219. 
source of power as is said of citizens; and, most important of all, corporations and states pursue profoundly different goals. ${ }^{47}$

\section{The current academic debate on sharebolder say}

Economic arguments found their way into the academic debate on shareholder power. Commentators have lined up on both sides of the debate over shareholder power, putting forward arguments for more or less shareholder power, or to defend the status quo. Shareholder primacists ${ }^{48}$ claim that shareholders have an investment at stake and thus have every interest in obtaining efficient decisions, adding further that shareholder power is necessary for democratic corporate decision-making and that the corporation is, in fact, a contract between shareholders, shareholders that delegate powers to the board as they see fit. Board primacists protest that shareholders are not specialized enough and pursue too many divergent interests, to make efficient decisions, whereas boards are subject to discipline from the market, liability rules and other legal techniques. Directors would also be better positioned to defend the interests of other constituencies than shareholders. Apart from the democratic and contractual arguments (which have been refuted in the previous Section), all these arguments are absolutely valid, and will for that reason be included in the further analysis in this article.

There are additional arguments that often recur in debates, but as these are unconvincing, they are left aside here. One of these is the argument that the existing distribution of power in American corporations has long served the

47 Peter Böckli, Aktionärsdemokratie: ein Schlagwort mit Schlagseite, GesKR 2013, 179; Holger Fleischer, Aktionärsdemokratie versus Verwaltungsmacht: Empowering Shareholders oder Director Primacy?, in Konvergenzen und Divergenzen IM DeutSCHEN, ÖSTERREICHISCHEN UND SCHWEIZERISCHEN GESELlSCHAFTS- UND KAPITALMARKTRECHT 81, 115 (Holger Fleischer et al. eds. 2011); Thomas W. Joo, “Corporate Governance and the D-Word”, 63 WASH. \& LeE L. Rev. 1586, 1587-88 (2006); Usha Rodrigues, The Seductive Comparison of Shareholder and Civic Democracy, 63 WasH. \& LeE L. Rev. 1389, 1399-1400 (2006); Robert B. Thompson \& Paul H. Edelman, Corporate Voting, 62 Vand. L. Rev.129,136(2009); Hans-Ueli Vogt, AKtionärsdemokratie 9 (2012); Hans-Ueli Vogt, Aktionärsdemokratie-Über die Möglichkeiten und Grenzen der Verwirklichung eines politischen Leitbildes im Aktienrecht, mit besonderer Berücksichtigung der Vorschläge für eine Revision des schweizerischen Aktienrechts in KONVERGENZEN UND DIVERGENZEN IM DEUTSCHEN, ÖSTERREICHISCHEN UND SCHWEIZERISCHEN Gesellschafts- und Kapitalmarktrecht 3, 12-14 (Holger Fleischer et al. eds. 2011).

48 This term will be used to indicate advocates of shareholder empowerment, although one could technical distinguish between primacy and power (Stephen M. Bainbridge, Director Primacy: The Means and Ends of Corporate Governance, 97 Nw. U. L. Rev. 547 (2003)). 
American economy well, the success of which would evidence that American corporate law is efficient as is. ${ }^{49}$ Both premises as well as the conclusion of this argument are flawed: Part I, Section 1 has demonstrated that the distribution of powers has not always been as it is today and the recent crisis casts doubt on the supposed optimal efficiency of the American economy. In addition, a strong economy is also as likely (if not more) to be the consequence of many other legal, economic, political and other factors..$^{50} \mathrm{~A}$ second indecisive argument is the claim that shareholders are, or are not, owners of the corporation. While the comparison with ownership has at least some surface appeal, it must be said that shareholders are not exactly owners in the legal sense, and especially do not behave as such in public companies. ${ }^{51}$ The "owner" label one does or does not attach to shareholders can hardly be a criterion to justify more or less shareholder power. ${ }^{52}$

A constraint of the more valid arguments mentioned above is that they are mostly used to increase or reduce shareholder power in a given legal system, but that if that happened, they could be used again for even more, or even less shareholder power. What we need is a general framework for an efficient distribution of powers that allows for drawing a line indicating how far all of these arguments can take shareholder or board power.

A now-classic theoretical framework on corporate decision-making was offered by Fama and Jensen. They argue that in organizations with many residual claimants, it is efficient for these residual claimants to delegate decisionmaking, because they are better at bearing residual risk, while directors are better at decision-making, subject to external monitoring from the market. This separation of risk bearing from decision making leads to a separation of decision control (i.e. ratification and monitoring) and decision management (i.e. initiation and implementation of decisions) at all levels of the firm. Decisions are thus made within the firm, although shareholders retain the right to elect directors and to ratify a few decisions. ${ }^{53}$ Another standard framework is

49 E.g. Stephen M. Bainbridge, Director Primacy and Shareholder Disempowerment, 119 Harv. L. Rev. 1735, 1739-40 (2006); Martin Lipton \& William Savitt, The Many Myths of Lucian Bebchuk, 93 VA. L. Rev. 733, 734 (2007).

50 Lucian A. Bebchuk, Letting Shareholders Set the Rules, 119 Harv. L. Rev. 1784, 179192 (2006).

51 Hans-Ueli Vogt, Aktionärsdemokratie 29-30 (2012). See however David C. Donald, Shareholder Voice And Its Opponents, 5 J. Corp. L. STUd. 305 (2005).

52 Grant Hayden \& Matthew T. Bodie, Shareholder Democracy and the Curious Turn Toward Board Primacy, 51 WM. \& MARY L. Rev. 2071, 2083 (2010); Lipton \& Savitt, supra note 49 , at 754 .

53 Eugene F. Fama \& Michael C. Jensen, Separation of Ownership and Control, 26 J.L. \& Econ. 301 (1983); Eugene F. Fama \& Michael C. Jensen, Agency Problems and Residual Claims, 26 J.L. \& Econ. 327 (1983). 
the team production theory formulated by Blair and Stout. They focus instead on various interests that are concerned in corporate decision-making, including those of non-shareholder constituents. In Blair and Stout's depiction of the corporation, the board acts as a mediator between these various interests, serving a broadly understood notion of corporate welfare. ${ }^{54}$ Less extreme is Bainbridge's conception of the board as "a platonic guardian - a sui generis body serving as the nexus for the various contracts making up the corporation and whose powers flow not from shareholders alone, but from the complete set of contracts constituting the firm", but still striving to maximize shareholder value..$^{55}$

These frameworks are enlightening as a general view of the corporation and seem to favor the board of directors in the allocation of corporate decisionmaking power, but they do not provide any guidance on precisely which powers should remain with the shareholder meeting. Bratton and Wachter, as well as Harris and Raviv, are more concrete when they describe the distribution of powers as a balancing exercise between agency costs within the board (see Part II, Section 1) and the informational disadvantage of the shareholder meeting. Only Harris and Raviv develop this insight into workable criteria but, as will be shown further, overlook some other important factors than incentives and informational differences. ${ }^{56}$ Dallas sees a role for control issues and conflicts of interest in the voting system, but mainly to explain requirements of approval by disinterested members. ${ }^{57}$

Several authors have attempted to categorize the matters for which the shareholder meeting should be competent in public companies. Eisenberg argues that, on the basis of the different skills between directors (business skills) and shareholders (investment skills), the economic significance of the matter, and the frequency and urgency of the decision, business decisions should be taken by board and management, while structural decisions and decisions regarding the control of the corporation should be taken by the shareholder

54 Margaret Blair \& Lynn Stout, A Team Production Theory of Corporate Law, 85 VA. L. Rev. 247 (1999).

55 Bainbridge, supra note 48, at 560; Stephen M. Bainbridge, The Board of Directors as Nexus of Contracts, 88 Iowa L. Rev. 1, 33 (2002). More extreme is the proposal of a selfperpetuating board, which is completely free from shareholder oversight, in order to allow it to strive for the company's long-term interests: Lawrence E. Mitchell, A Critical Look at Corporate Governance, 45 VAND. L. Rev. 1263, 1272 (1992).

56 William W. Bratton \& Michael L. Wachter, The Case Against Shareholder Empowerment, 158 U. PA. L. Rev. 653, 659-60, 665-66 (2010); Milton Harris \& Artur Raviv, Control of Corporate Decisions: Shareholders vs. Management, 23 REv. FIn. ST. 4115 (2010).

57 Lynne L. Dallas, The Control and Conflict of Interest Voting Systems, 71 N.C.L. Rev. 1, 71 (1992). 
meeting. ${ }^{58}$ In a more recent proposal to improve American corporate law, Bebchuk advocates shareholder intervention power for two categories of decisions: (1) decisions to amend the corporate charter or to change the company's state of incorporation, in order to provide some counterweight to the practical advantage management has in corporate decision-making, and (2) business decisions of substantial importance, namely decisions to merge, sell all assets, or dissolve the company and decisions which reduce the company's size by ordering a cash or in-kind distribution. Shareholder power for these matters would be founded on the fact that agency costs (see Part II, Section 1) in these decisions are particularly high. ${ }^{59}$ On the European side of the debate, Vogt advances three factors that should guide the allocation of powers between the board and the shareholder meeting. The task must fit:

(1) the function of the organ as it results from evolution and economic logic (mainly the shareholders' role as providers of capital financing, their limited liability, the fact that decisions of the shareholder meeting are practically limited to binary choice between yes or no, and, for the board, its role as the centralized decision-maker that is subject to fiduciary duties),

(2) the form of each corporate organ (its composition, size, decision-making procedure and information available), and

(3) the relative appropriateness for the task of the corporate body in the corporate system..$^{60}$

While the last views point to essential factors in an efficient distribution of powers, it is still not entirely clear how to balance the different factors and turn them into workable criteria that can be applied consistently to all matters that come up during a company's life cycle. Building on extant literature, such a consistency is precisely what the following Part will attempt to establish.

\section{An economically efficient criterion for allocating corporate power}

The first Part has shown that, although lawmakers were concerned about economic efficiency in designing the corporate decision-making structure, they had no clear criterion by which to achieve this goal. In the meantime, a

58 Melvin A. Eisenberg, The Legal Roles of Shareholders and Managers in Corporate Decisionmaking, 57 CAL. L. REv. 1, 10-13, 59-60 (1969).

59 Lucian A. Bebchuk, The Case for Increasing Shareholder Power, 118 HARv. L. Rev. 833 (2005).

60 Vogt, in Konvergenzen und Divergenzen, supra note 47, at 21-40; Hans-Ueli Vogt, Aktionärsdemokratie 23-45, 73-81 (2012). 
wealth of economic analytical tools and empirical evidence is now at our disposal. This Part will use this new knowledge to advance criteria for an economically efficient distribution of corporate powers. It will be argued that the key lies in a combined transaction cost and agency cost approach and that this leads to criteria based on what I call "inherent" conflicts of interest. This Part then ends with a brief application of these criteria.

\section{An integrated view on transaction costs and agency costs}

In Coase's theory of the firm, the reason of existence for firms lies in the cost associated with the use of the price mechanism that steers the markets. In the market, actors have to search for providers of the desired products, bargain for an agreement, and enforce it - all of which entail "transaction costs". By replacing negotiations in the market with decisions based on authority within the institutional framework of the firm, these costs can be significantly reduced. ${ }^{61}$ What is lesser known, however, is that transaction costs do not only exist in the market (external transaction costs), but also within every contractual relationship and every firm (internal transaction costs). ${ }^{62}$ The "transaction" can thus refer both to a contractual transaction in a market environment, but also to more institutional forms of economic coordination. ${ }^{63}$ Some economists took the argument a bit further and opined that the firm is nothing more than a nexus of contracts with shareholders, employees, creditors, suppliers, etc. ${ }^{64}$ In any event, the finding that transaction costs also occur within the firm demonstrates the relevance of Coase's theory to the internal distribution of corporate powers.

The transaction cost theory falls short in that it assumes that managers exclusively pursue the corporate interest. Agency theory fills this gap by building on the claim of the managerial theory that managers (and directors) max-

61 Ronald Coase, The Nature of the Firm, Economica 386, 390 (1937), reprinted in Ronald Coase, The Firm, The Market, and The Law 33, 38 (1988); Ronald Coase, The Problem of Social Cost, 3 J. L. \& Econ. 1, 15-19 (1960).

62 See Steven N.S. Cheung, A Theory of Share Tenancy (1969). In the neoclassical theory, the notion of transaction costs remained restricted to costs of market transactions between firms or individuals (Douglas W. Allen, Transaction Costs, in ENCYClopedia of Law and Economics, I. The History and Methodology of Law and Economics 893, 902-03, 904-06 (Boudewijn Bouckaert \& Gerrit De Geest eds., 2000).

63 M. Klaes, History of Transaction Costs, in The New Palgrave Dictionary of EcoNOMics (Steven N. Durlauf \& Lawrence E. Blume eds., $2^{\text {nd }}$ ed. 2008).

64 Frank Easterbrook \& Daniel Fischel, The Economic Structure of Corporate LAw 12 (1996); Michael C. Jensen \& William H. Meckling, Theory of the Firm: Managerial Behavior, Agency Costs and Ownership Structure, 3 J. Fin. Econ. 305, 310-11 (1976). 
imize their own utility. ${ }^{65}$ Agency is to be understood broadly here as every relationship in which one party - the agent - performs a service on behalf of the other party - the principal - and which entails a certain delegation of decision-making power. ${ }^{66}$ In corporate law, the so-called "first" agency problem refers to the relationship between directors and shareholders when the latter are not directors themselves (regarding the influence of the "second" and the "third" agency problem, see Part III, Sections 3 and 4). In case of such a separation of ownership and control, managers and directors (seen as agents) do not always have an interest in pursuing the interest of the shareholders (seen as the principal) as they do not receive all profits or bear all costs that they generate for it. ${ }^{67}$ All profits forgone and costs incurred by the divergence of interests between principal and agent are called agency costs. ${ }^{68}$ The first agency conflict is more intense the more fragmented the shareholder basis because dispersed shareholders generally loosen the reins. ${ }^{69}$

To integrate the transaction cost theory and the agency theory, one has to keep in mind the different focus of each theory. While agency theory studies the individual and his incentives, the transaction cost theory analyses and compares transactions. ${ }^{70}$ To a large extent, each theory therefore spotlights a cost of which the other theory does not take notice and to this extent both theories are complementary. ${ }^{71}$ Nevertheless, some similarities exist between both, resulting in overlaps between the notions of agency costs and transaction costs. Which label to stick on these costs is then purely a question of semantics. ${ }^{72}$ What is clear, however, is that the company is internally confronted both with transaction costs and with agency costs. In the context of decision-making in the boardroom and within the shareholder meeting, the transaction costs are

65 William J. Baumol, Business Behavior, Value and Growth (1959) (managers striving for revenues rather than profits); Robin Marris, The Economic Theory of 'Managerial' Capitalism (1964) (managers focusing too much on growth); Oliver E. Williamson, The Economics of Discretionary Behavior: Managerial ObjecTIVES IN A TheOry of THE Firm (1964) (managers taking private benefits).

66 Jensen \& Meckling, supra note 64, at 308-09; Martin Hellwig, On the Economics and Politics of Corporate Finance and Corporate Control, in Corporate Governance: Theoretical and Empirical Perspectives 103 (Xavier Vives ed., 2000).

67 J. Armour et al., Agency Problems and Legal Strategies, in The Anatomy of CorpoRate Law 36 (R. KraAkman et al. eds., $2^{\text {nd }}$ ed. 2009).

68 These include monitoring costs, bonding costs, and residual loss (Jensen \& Meckling, supra note 64 , at 308 ).

69 Armour et al., supra note 67, at 52.

70 Oliver E. Williamson, The Mechanisms of Governance 179 (1996).

71 See also Jensen \& Meckling, supra note 64, at 308.

72 See Harold Demsetz, The Theory of the Firm Revisited, 4 J. L. Econ. \& Org. 141, 144 45 (1988). 
not exactly contracting costs but rather "decision-making costs" ${ }^{73}$ Decisionmaking costs include costs of gathering and processing information, deliberation, and decision by a meeting of shareholders or directors, assuming they exclusively pursue the corporate interest. Costs arising from them pursuing their private interest and from attempts to reduce these costs will be indicated as agency costs.

\section{Cost comparison of board and shareholder meeting}

With regard to decision-making costs, the board of directors has an obvious edge over the shareholder meeting: the board is easier to convene, its members are more specialized and have better access to information, fewer have to process information, and information can be kept confidential. ${ }^{74}$ Convening a shareholder meeting, by contrast, is costly in many more ways than the practical expenses of notice. Shareholders are (generally) not nearly as specialized and knowledgeable about the company's situation; ${ }^{75}$ shareholders will often not bother going through all of the information available; and any information shared with shareholders of a public company will likely be read by competitors in the first place. The costs of sound decision-making by the shareholders themselves (see Part III, Section 2 regarding proxy advising) will always remain prohibitively high in a public company. ${ }^{76}$ Even when new communication techniques can ensure free delivery of information and distance voting, a large crowd of shareholders would still have to process infor-

73 See e.g. D. Gordon Smith, The Role of Shareholders in the Modern American Corporation, in Research Handbook on the Economics of Corporate Law 52 (Claire A. Hill \& Brett H. McDonnell eds., 2012). The notion of "governance costs" (e.g. used by Luca EnRIQues et al., The Basic Governance Structure: The Interests of Shareholders as a Class, in The Anatomy of Corporate Law 55, 72, n. 93 (R. Kraakman et al. eds., $2^{\text {nd }}$ ed. 2009)) will not be employed here, because it is often understood to also cover agency costs (e.g. Jeffrey N. Gordon, Pathways to Corporate Convergence? Two Steps on the Road to Shareholder Capitalism in Germany, 5. Colum. J. Eur. L. 219, 222 (1998-99)) and as a consequence it does not allow to weigh decision-making costs against agency costs.

74 See Bainbridge, supra note 49, at 1745-46, 1749; Leo E. Strine, Jr., Toward a True Corporate Republic: A Traditionalist Response to Bebchuk's Solution for Improving Corporate America, 119 Harv. L. Rev. 1759, 1763 (2006).

75 See Bratton \& Wachter, supra note 56, at 688-709 (arguing that shareholders rely on the information included in the stock price, but that in the absence of a strong-form efficient capital market, this leads to inefficient decisions). See however Lucian A. Bebchuk, The Case Against Board Veto in Corporate Takeovers, 69 U. CHI. L. Rev. 973, 978 (2002) (arguing that informational disadvantages can often be overcome by means of welldesigned legal rules on communicating information to the shareholders).

76 See Henry Hansmann, The Ownership of Enterprise 40-42 (1996). 
mation and form opinions on sometimes highly complex matters. All solutions that have been put forward so far, such as attendance fees, or an enhanced role for institutional investors and proxy advisors, trigger their own costs (see also Part III, Section 2). From the perspective of decision-making costs, one can conclude, the company benefits from allocating as many powers as possible to the board of directors.

From the perspective of the costs stemming from the first agency conflict, yet, the shareholder meeting is in a better position to decide. Conventional wisdom (see Part III for some qualifications) dictates that shareholders have the best incentives to promote the corporate interest ${ }^{77}$ because they are residual claimants or, formulated negatively, residual risk bearers. ${ }^{78}$ Indeed, shareholders are only entitled to share in whatever is left of the profits after payment of creditors' fixed claims. Shareholders therefore have every interest in the company being able to pay off its debts and even earning more than that, and to contribute to that by making efficient decisions and monitoring both the board and management. ${ }^{79}$ Directors, on the contrary, do not have any such natural incentives from their position alone. As the above description of the first agency conflict made evident, directors frequently have very different interests than maximizing corporate value.

\section{Conflicts of interest as normative criterion}

With the two main cost concepts under our belt, it is easier to discern the key elements that should guide the allocation of decision-making authority be-

77 E.g. Frank H. Easterbrook \& Daniel R. Fischel, Voting in Corporate Law, 26 J. L. \& Econ. 395, 403-04 (1983); William T. Allen et al., Commentaries and Cases on the Law of Business Organization 452 (3rd ed. 2009).

78 In an unpublished paper, Black argues that stakeholders are residual claimants too: Bernard S. Black, Corporate Law and Residual Claimants, Stanford Law and Economics Olin Working Paper 2001, No. 217 (available at http://papers.ssrn.com/sol3/papers.cfm?abstract_id=1528437). Hayden and Bodie argue that the residual claim of the shareholders should not be taken for granted, and that because of shareholders' increasing heterogeneity stakeholders should receive voting rights as well (Grant Hayden \& Matthew Bodie, Arrow's Theorem and the Exclusive Shareholder Franchise, 62 Vand. L. Rev. 1217 (2009); Hayden \& Bodie, supra note 52). See also Andrew Keay, Shareholder Primacy in Corporate Law: Can it Survive? Should it Survive?, 7 ECFR 369, 378-80 (2010).

79 Report of the High Level Group of Company Law Experts on a Modern Regulatory Framework for Company Law in Europe, November 4, 2002, 47; Armen A. Alchian \& Harold Demsetz, Production, Information Costs, and Economic Organization, 62 Ам. ECON. Rev. 777, 782 (1972); EASTERBRooK \& Fischel, supra note 64, at 67-70, 72; Easterbrook \& Fischel, supra note 77, at 408; Fama \& Jensen, supra note 53, at 301-03. 
tween directors and shareholders. While it is almost impossible to quantify and mathematically compare agency and transaction costs - how much value is lost when thousands of shareholders have to process information and/or make a suboptimal decision? -, we do know some factors that affect their relative importance: the subject matter of the decision and the number of shareholders. Transaction costs, or, in this context, decision-making costs, fluctuate with the number of shareholders. For lawmakers, this could certainly justify a distinction between public and private firms, but within public companies (the group investigated in this article) it can hardly be a criterion of distinction because they have numerous shareholders in any case ${ }^{80}$ and a distinction would not be practically feasible. The subject matter of a decision, in contrast, and in particular the question whether the matter involves divergent interests of directors, has a tremendous influence on agency costs even within the category of public corporations. The decisive criterion in an efficient distribution of powers must therefore be whether directors have conflicts of interest in a given matter.

In matters where the incentives of directors do not diverge from those of the shareholders, the costs of the first agency conflict, when the board of directors makes the decision, remain limited. Relatively speaking, the higher decisionmaking costs of the shareholder meeting then weigh heavier and board authority is warranted. Conversely, in matters where directors' interests are opposed to those of the shareholders, agency costs amplify and, as board decisions could be tainted by personal interests, directors' superior information and specialization advantage loses its value. ${ }^{81}$

Directors' conflicts of interest can either relate to the essence of a decision or to a side aspect of it. A decision that directly concerns the director's interest is important enough by its nature to justify a shareholder vote. Section 5 will show that there are not only direct effects on agency costs involved in making such a decision (ex post agency costs), but that shareholder power can also substantially curb agency costs without being exercised effectively (ex ante agency costs), while the transaction costs associated with the decision remain relatively low. In matters where directors do not face conflicting interests with respect to the essence of the decision, but only with respect to a side aspect of the decision, this oblique conflict can still induce a director to make an inefficient overall decision. Provided that the decision is material for the company, such an indirect conflict of interest can also affect shareholder value to such an extent as to make decision-making by the shareholder meeting advisable. Moreover, the materiality of a decision can also influence decision-mak-

80 The existence of a controlling shareholder is a different matter, which will be discussed in Part III, Section 3.

81 Bebchuk, supra note 75, at 999-1004. 
ing costs. Important decisions, such as restructurings, become less of a management decision and resemble investment decisions, in which shareholders are not, as a rule, less specialized than directors and managers. ${ }^{82}$ Importance is also likely to motivate more shareholders to win over the collective action problem and to effectively participate in the vote ${ }^{83}$ Conversely, organizing a shareholder meeting is not worth the high decision-making costs for small decisions, such as daily management, ${ }^{84}$ even if they cause small agency costs. Shareholders should, for that reason, not micromanage the firm's management. ${ }^{85}$

\section{Difference with conflict of interest procedures and related party transactions}

A critical reader might object that corporate laws have special regulations on conflicts of interest and related party transactions and that power allocation must for that reason be based on different criteria. Yet, there is a crucial distinction between the above-defended criterion of conflicting interests and those targeted by conflict of interest procedures and rules on related party transactions (even if the related party is a director). The divergence of interests that justifies shareholder power is inherent to the position of director in the company that makes the decision, given the subject matter of the decision. It is the mere fact of being a director that causes the conflict of interest on matters like director remuneration. As a consequence, the entire board will, in principle, be conflicted each time decisions need to be made in those matters. The conflicts of interest in the sense of the special procedures and related party transactions are fundamentally different. They are not inherently related to the subject matter of the decision, ${ }^{86}$ but result instead from concrete circumstances, like the director's other functions (in the same or in another company), his personal relationships, the fact that he is a counterparty to the agreement being decided on, etc. As a consequence, these conflicts of interest do, in principle, not affect all board members.

Two precisions are in order at this stage. First, for there to be an inherent conflict of interest, a decision need not relate to all board members. Even a decision formally concerning only one director may create conflicting interests for all directors when the same kind of decision needs to be made for them,

82 Eisenberg, supra note 58, at 50; FleISCHER, supra note 5, at 448.

83 Easterbrook \& Fischel, supra note 77, at 416; Eisenberg, supra note 58, at 50.

84 See Allen ET AL, supra note 77, at 451.

85 Roger Barker, Ownership Structure and Shareholder Engagement: Reflections on the Role of Institutional Shareholders in the Financial Crisis, in Corporate GovernanCE And the Global Financial Crisis 144, 148 (William Sun et al. eds., 2011).

86 Merle, supra note 13, at 477-78. 
such as a decision on remuneration. In these kinds of decisions, directors risk mutually supporting each other's generous remuneration merely with a view to receiving the same support when their own compensation package is tabled. This phenomenon of mutual backscratching is said to effectively occur in jurisdictions where director remuneration is determined by the board of directors, like the United States. ${ }^{87}$ Second, the above explanation regularly includes the qualification "in principle". This is because the assessment of inherent conflicts of interest is made in abstracto. It does not matter whether directors are, in fact, driven by their conflicting interests in a given situation, or whether their biased opinion has influenced the eventual decision.

The different natures of the two described types of conflicts of interest call for different legal strategies to deal with each of them. The conflicts of interest procedure and rules on related party transactions therefore do not make the authority of the shareholder meeting redundant as a strategy to deal with inherent conflicts and, as we will see, in fact support the validity of the criterion of inherent conflicts of interest.

The strategies employed by conflict of interest procedures and related party transactions rules can be divided into roughly three categories. The first category contains information and justification requirements for conflicted persons and boards with conflicted directors, which is mostly part of a larger procedure..$^{88}$ The second category requires conflicted persons to abstain from deliberation and/or voting; rules within this category are usually mandatory, ${ }^{89}$ but only encouraged in the United States, where approval by disinterested directors can, under certain conditions, both shift and heighten the burden of proof if the decision is challenged in court. ${ }^{90}$ The third category shifts authority to another corporate body when directors face conflicting interests. This technique is mainly used in two-tiered boards, e.g. in Germany ${ }^{91}$ and the

87 With regard to CEO remuneration: Lucian A. Bebchuk \& Jesse Fried, Pay without Performance: Overview of the Issues, 30 J. Corp. L. 647, 654-59 (2005).

88 See Luca Enriques et al., Related Party Transactions, in The Anatomy of Corporate LAw 153, 155-61 (Reinier Kraakman et al. eds., 2nd ed. 2009); Klaus J. Hopt, Conflict of Interest, Secrecy and Insider Information of Directors, A Comparative Analysis, 10 ECFR 167, 186 (2013).

89 E.g. art. 2:129, $\$ 6 \& 2: 140, \$ 5$ Dutch Civil Code (as recently amended); art. L225-40, $\$ 1$ \& L. 225-86, \$1 French Commercial Code (for so-called “regulated agreements”); art. $523 \$ 1$ Belgian Companies Code (for public companies).

90 Allen et al., supra note 77, at 314-26; Eric G. Orlinsky, Corporate Opportunity Doctrine and Interested Director Transactions: A Framework for Analysis in an Attempt to Restore Predictability, 24 Del. J. CoRp. L. 451, 519 (1999).

91 The supervisory board must represent the company in matters in which a member of the

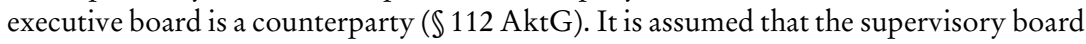
then also acquires decision-making power (2 Münchener Kommentar zum AkTien- 
Netherlands, ${ }^{92}$ where a conflict within the management board shifts the decision to the supervisory board. Less drastic is the solution whereby the decision-making authority is only moved partially, i.e. the board still makes the decision, but it must obtain approval from another body and/or specific (e.g. independent) members of the board..$^{93}$ Only in exceptional cases of conflicts of interest within the board will the decision-making authority shift to the shareholder meeting. ${ }^{94}$ This is mostly a second order solution, occurring when decision-making by the board is paralyzed because too many directors are excluded from participating due to conflicts of interest (see further in this Section).

Of all these strategies, only the very last one can effectively address inherent conflicts of interest. The first category - the information and justification obligation - is useless because an inherent conflict affects all directors and does not depend on the concrete circumstances; everyone is, in any case, aware of the conflict. Neither will a statement by the conflicted director have a disciplining effect - the other directors will not discount the conflicted director's opinion if they have similar interests. The same holds for requiring abstention or partial shifts of competence. Since all directors are, in principle, conflicted, there would be none left to make the decision.

The last strategy - moving authority to the shareholder meeting - is precisely what has been defended above for inherent conflict of interest. Not surprisingly, this strategy is used in conflict of interest situations and related party transactions that, despite not being inherent conflicts of interest, closely resemble them, namely when all directors, or at least a majority of them, have conflicting interests. ${ }^{95}$ In these situations, the authority of the shareholder meeting is prescribed for instance in the new Dutch conflict of interest

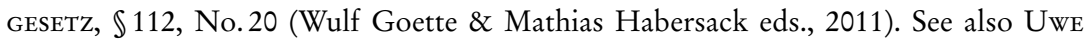
Huffer, Aktiengesetz $\ 112$, No. 4 (2012)).

92 In the Netherlands, this is the case when the abstention duty renders decision-making in the executive board impossible, unless the articles of association stipulate otherwise (Art. 2:139, $\$ 6$ Dutch Civil Code).

93 E.g. art. 10 \& 21 p Amended Proposal for a Fifth Directive, 1983 O.J. (C 240) 2; art. 225 40 \& 225-88 French Commercial Code (for so-called “regulated agreements").

94 OECD, Related Party Transactions and Minority Shareholder Rights, Parijs, OECD Publishing, 2012, 34; Luca Enriques et al., supra note 88, at 166-67; Hopt, supra note 88, at 187.

95 Related party transactions with controlling shareholders are a special case. Because the shareholder controls the composition of the board, one might conjecture that all board members are conflicted. Moving the decision to the shareholder meeting will not be of much avail though, because of the controlling shareholder's weight in the vote, and special majority requirements would create a risk of opportunistic hold-up by minority shareholders (see Enriques et al, supra note 88, at 179-82). Independent directors may be the best solution, since the conflict is not inherent to the position of director. 
regime $^{96}$ and has also been advocated more generally in Belgian legal doctrine. ${ }^{97}$ In Delaware, the possibility to table the decision in the shareholder meeting is not legally limited to situations where all directors are conflicted, but it is mainly used in those cases. ${ }^{98} \mathrm{It}$ is on the basis of a similar reasoning, that the German conflict of interest provisions shift authority from the management board to the supervisory board even if just one member of the former is conflicted (see above). The underlying idea is that other members of the management board would not be able to decide objectively about a transaction in which a colleague is involved. ${ }^{99}$ Somehow this could be read as a drastic application of the rule that when all directors are conflicted, authority should transfer to another corporate body. In the context of the German dual board, this is a reasonable choice because a transfer to the supervisory board causes fewer transaction costs than a transfer to a shareholder meeting (the only option in a monistic structure). Correspondingly, dual tier structures also allow more flexibility in the allocation of powers in response to inherent conflicts of interest (see Part III).

When the law responds to concrete conflicts of interest by shifting authority, it exhibits the same intuition as the one that underlies the power allocation model advocated here, namely that shifting authority is the best solution when (almost) all directors are conflicted. The difference between inherent conflicts of interest and concrete conflicts of interest that exceptionally affect (nearly) all directors is in the cause of the conflict, the first being systematic and the second depending on concrete circumstances. For the latter, the law cannot but rely on the directors themselves to apply a procedure in which they assess who is conflicted to decide if authority must shift to another organ; for the former, the law can directly give authority over to the shareholder meeting (or, in a dual system, the supervisory board). The criterion of inherent conflicts of interest thus fits well into the existing legal framework and is, in fact, an application of its underlying principles.

96 Art. 2:140, $\$ 5$ Dutch Civil Code.

97 P.-A. Foriers, Les situations de blocage dans les sociétés anonymes, TBH 466, 470 (1992);

F. Hellemans, De algemene vergadering 554 (2001); H. Laga, Belangenconflicten, aantal bestuurders en schriftelijke besluitvorming in de N.V., in De NIEUwe VennootSCHAPswetten van 7 EN 13 april 1995, 175, 194 (1995); Jan Ronse, Algemeen deEL 405 (1975); J.-F. Tossens \& C. Bertsch, Les situations de blocage au sein du conseil d'administration de la société anonyme à la suite de l'application de l'article 60 L.C.S.C. relatif à la dualité d'intérêts, Rev. Prat. Soc. 32, 36-37 (1995); J. Verhaert, Patstellingen in vennootschappen, RW 161, 171-72 (1994-95).

98 Orlinsky, supra note 90 , at 465.

99 MünCHENER KommentaR, supra note 91 , at $\ 112$, No. 1; Huffer, supra note 91, at $\ 112$, No.1. 


\section{A brief application}

Conflicts of interest inherent to the function of directors can arise in decisions that directly or indirectly concern the position of director, directors' personal benefits or disadvantages, and/or the scope of their power. ${ }^{100}$ The following sketch is by no means an exhaustive account of all respective powers of the shareholder meeting and the board of directors. How the powers of the shareholder meeting should be framed exactly, and whether delegation possibilities, demand requirements and similar techniques of cooperation with the board should be allowed, extends beyond the scope of this article.

In certain matters, directors' interests are directly opposed to the corporate interest. The position of the directors is obviously directly concerned in decisions on their election and dismissal, in which case the conflicting interests are apparent. ${ }^{101}$ At the same time, the board's transaction cost advantage is relatively low in the choice of a director, as it does not require much specialization or time investment. An additional reason for shareholder authority in appointment and removal decisions is that it curbs agency costs ex ante. Indeed, removal is not only a powerful remedy against poorly performing directors, but the mere threat of removal also has a disciplining effect. ${ }^{102}$ The potential for a shareholder meeting to remove directors is further crucial for the takeover market to function properly and have a disciplining effect. For these reasons, directors should not be able to decide on their own position, or to influence a shareholder decision (in other words, partially make the decision themselves) through mechanisms such as extravagant severance payment commitments or staggered boards. The markets would not even be able to properly sanction any such restrictions of shareholder power, precisely because these restrictions erode the discipline effect of the markets. ${ }^{103}$

In the category of directors' personal benefits and advantages, decisions on director remuneration and liability claims against directors engender inherent conflicts of interest. Because these decisions are technically complex and costly

100 See also, in the context of the choice between mandatory and default law, Lucian A. Bebchuk, Federalism and the Corporation: The Desirable Limits on State Competition in Corporate Law, 105 HARv. L. REv. 1435, 1461 (1992) ("there are two types of issues with respect to which market discipline can hardly be relied on to induce managers to seek value-maximizing rules. These two types of issues are those that are 'significantly redistributive' and those that directly affect the strength of market discipline."); Melvin A. Eisenberg, The Structure of Corporation Law, 89 Colum. L. Rev. 1461, 1472 (1989) (delineating a comparable category of "positional conflicts" and arguing that legal provisions dealing with these conflict should be mandatory).

101 See e.g. Report of the High Level Group, supra note 79, at 60.

102 Bebchuk, supra note 59, at 878; EASTERBRooK \& Fischel, supra note 64, at 76.

103 Bebchuk, supra note 100 , at 1468 . 
in terms of transaction costs, ${ }^{104}$ shareholders may not have to agree with all details, but should still have a say. ${ }^{105}$ Finally, the scope of directors' power is at stake in decisions on the payment of dividends. Specifically, dividend payouts reduce the freedom for directors to pursue projects of their choice. ${ }^{106}$

Sometimes the inherent conflict of interest does not relate to the essence of the decision, but only to an aspect of it. In these matters, as discussed above, the decision should belong to the shareholder meeting if the decision itself is material to the company. Material decisions include fundamental changes to the company, in which case even side conflicts may give rise to significant agency costs. Indeed, the "reduction of agency costs is the most probable explanation for shareholders' voting on fundamental corporate changes. Shareholders, as residual claimants, have the most to lose (or to gain) as a result of fundamental corporate changes. Moreover, the possibility of large gain or loss in these transactions because of their size is sufficient to overcome the collective action problems, particularly for institutional investors, that would make voting on ordinary business decisions meaningless." 107

Most jurisdictions do indeed require a shareholder vote for structural changes that are large and that may create conflicts of interest for directors. ${ }^{108}$ Fundamental changes, like mergers, dissolutions, and takeover defenses, almost invariably present conflicting interests for directors and managers. ${ }^{109}$ Although directors and managers derive benefits from pursuing value-generating projects, ${ }^{110}$ they also face inherent conflicts of interest obliquely when a merger or dissolution is on the table or when the company is the target of a takeover bid. First, these transactions risk reducing their control over the corporation ${ }^{111}$ and, in the case of dissolution, will automatically terminate their mandate. Consequently, a shareholder vote on a merger in practice often boils down to a confidence vote or a mid-term election. ${ }^{112}$ Second, in these transactions, directors may try to negotiate personal benefits, like an increase in pay or a generous departure compensation, and risk basing their ultimate decision on whether or not to consummate the transaction on these side benefits instead of

104 FleIsCHER, supra note 47, at 102.

105 Hans-Ueli Vogt, Aktionärsdemokratie 44, 50-59 (2012).

106 Bebchuk, supra note 59, at 903-04; Michael C. Jensen, Agency Costs of Free Cash Flow, Corporate Finance and Takeovers, 76 Am. Econ. Rev. 323 (1986).

107 Easterbrook \& Fischel, supra note 77, at 416.

108 Edward Rock et al., Fundamental Changes, in The Anatomy of Corporate Law 183, 184 (Reinier Kraakman et al. eds., $2^{\text {nd }}$ ed. 2009).

109 Eisenberg, supra note 58, at 27-30; Rock et al., supra note 108, at 199-202.

110 Richard P. Castanias \& Constance E. Helfat, Managerial and Windfall Rents in the Market for Corporate Control, 18 J. Econ. Behavior \& ORg. 153 (1992).

111 Bebchuk, supra note 59, at 897-99.

112 Easterbrook \& Fischel, supra note 77, at 416. 
the efficiency of the transaction. ${ }^{113}$ It is because of these conflicting interests that shareholders are better positioned to decide on mergers, dissolutions and the company's response to takeover bids (including ex ante measures such as poison pills).

Inherent conflicts of interest also arise when a company seeks to acquire another company or to invest in important assets. Such acquisitions, if successful, have side benefits in terms of directors' power and prestige as the directors will then be leading a larger firm (empire building) and with this often comes an increase in their remuneration, if based on factors like sales growth or turnover. ${ }^{114}$ Combined with the bias against disgorging cash to shareholders (see above), this may lead directors and managers of firms with free cash flow to prefer inefficient acquisitions over dividend distributions. Moreover, acquisitions entail indirect agency costs in that they intensify the conflict of interest between board and management on the one hand and shareholders on the other hand. ${ }^{115}$ Not only is it mostly associated with further dispersion of stock ownership, but also the diversification of activities allows the company to reduce the volatility of its revenues, thus increasing the likelihood of the company's survival and safeguarding directors' positions. ${ }^{116}$

The proposed framework is not limited to supporting the authority of the shareholder meeting. In the absence of conflicts of interest and/or materiality, board authority is the more efficient option. The amendment of the company's articles of association is a good illustration of the different consequences of the proposed criterion. In continental Europe, companies typically have one constitutional document, which can be amended only by the shareholder meeting. ${ }^{117}$ However, these articles of association often include provisions of which the board of directors can more easily take care than the shareholder meeting and in which no conflict of interest is present, such as the name of the company, the accounting year, the precise address of the corporate seat (to the extent that it does not influence applicable law) etc. Conflicts can arise, however, over other sections of the articles of association. In addition to the fundamental changes discussed above, as well as entrenchment provisions to thwart these changes, ${ }^{118}$ one example is the jurisdiction of incorporation, because it determines applicable law and thus also the degree of board autonomy.

113 Paul Davies \& Klaus Hopt, Control Transactions, in The Anatomy of Corporate LAw 225, 228 (Reinier Kraakman et al. eds., 2nd ed. 2009).

114 Jensen, supra note 106, at 323.

115 Ronald W. Masulis et al., Corporate Governance and Acquirer Returns, 62 J. Fin. 1851, 1852 (2007).

116 Yakov Amihud \& Baruch Lev, Risk Reduction as a Managerial Motive for Conglomerate Mergers, 12 BeLl J. Econ. 605 (1981).

117 Matthias M. Siems, Convergence in Shareholder Law 162 (2008).

118 Rock et al., supra note 108, at 190. 
Conflicts can also be found in provisions relating to shareholder voting and dividend rights. Especially in concentrated ownership structures where directors are appointed and supported by one or more large shareholders, directors could be tempted (or forced) to use any power they would have to allocate to these shareholders preferential or increased dividend rights, multiple voting rights or a special role in director nomination or appointment procedures. ${ }^{119}$ With regard to a company's articles of association, the proposed framework would, therefore, support differentiating between provisions that the board can amend and those that belong to the exclusive competence of the shareholder meeting.

\section{$I V$. Counterarguments and refinements}

It might be argued that the proposed normative criterion of inherent conflicts of interest is not very different from a focus on the first agency problem and that several important arguments in the shareholder democracy debate have been neglected. This Part succinctly considers these remaining arguments and investigates if they require that the proposed criterion be further refined. An important finding will be that many objections fall flat in light of the inherent nature of the conflicts of interest that, as argued above, should bolster shareholder power.

\section{Market discipline and legal agency strategies}

One possible objection against reverting to shareholder power anytime directors face an inherent conflict of interest is that there is a myriad of other mechanisms that mitigate the first agency conflict (other than the rules on conflict of interest and related party transactions, which have been discussed above). To a certain extent the first agency conflict is indeed kept in check by the product market, ${ }^{120}$ the managerial labor market, ${ }^{121}$ the capital market ${ }^{122}$ and the market for corporate control. ${ }^{123}$ In addition to these economic mech-

119 Rock et al., supra note 108, at 190-92.

120 Oliver D. Hart, The Market Mechanism as an Incentive Scheme, 14 BeLl J. Econ. 366, 367 (1983); Jensen, supra note 106, at 323.

121 Eugene F. Fama, Agency Problems and Theory of the Firm, 88 J. Pol. Econ. 288, 292 (1980); Daniel R. Fischel, The 'Race to the Bottom' Revisited: Reflections on Recent Developments in Delaware's Corporation Law, 76 Nw. U. L. Rev. 913, 919 (1982).

122 Jensen, supra note 106, at 323.

123 Henry G. Manne, Mergers and the Markets for Corporate Control, 73 J. Pol. Econ. 1965, (110) 112-113; Michael C. Jensen \& Richard S. Ruback, The Market for Corporate Control: The Scientific Evidence, J. Fin. Econ. 5, 42-45 (1983). 
anisms, there are legal strategies, such as rules which prescribe or forbid specific behaviors (e.g. the corporate opportunities doctrine and rules prohibiting competition with the company), liability standards, disclosure obligations, exit possibilities for shareholders, variable remuneration, independent directors, etc. ${ }^{124}$ As a consequence, it is argued, directors and managers are well aware of their duties ${ }^{125}$ and subject to forceful incentives to act in the corporate interest. ${ }^{126}$ Shareholder power, which is, in fact, itself a legal agency strategy to deal with agency conflicts (the "appointment rights strategy" and the "decision rights strategy"), should then be used only exceptionally because it is the most drastic of these strategies; it boils down to undoing the agency relationship for certain matters.

The above mechanisms do mitigate the first agency conflict but not sufficiently. First, the discipline effect of the markets is limited. ${ }^{127}$ The disciplining effect of the capital market is easy to circumvent. Many firms can satisfy their financing needs with retained profits so that they only sporadically have to appeal to the capital market. ${ }^{128}$ Even when they have to, poor performance merely increases the costs of capital, meaning that securities are sold at a lower price, the financial consequences of which are suffered in the first place by the shareholders. ${ }^{129}$ Similarly, a weak competitive position in the product market is mainly detrimental for the shareholders ${ }^{130}$ and the discipline coming from it can significantly be hampered in case of an oligopoly or monopoly. ${ }^{131}$ Too much reliance on the market for managers and directors is not warranted either: even if poor performance negatively affects the stock price, in reality it seldom leads to dismissal of directors and/or top management, at least in jurisdictions with weak shareholder power, like the United States. ${ }^{132}$ In the takeover market, directors often have a host of techniques available to protect against hostile takeovers -especially in the United States - so that potential

124 Armour et al., supra note 67, at 39-45; EnRIQues et al, supra note 73, at 78-82.

125 Lipton \& Savitt, supra note 49, at 749-54.

126 E.g. Bainbridge, supra note 49, at 1740, 1746-47; James McConvill, The False Promise of Pay For Performance: Embracing a Positive Model of the ComPany Executive 42-51 (2005). See also Bratton \& Wachter, supra note 56, at 675-88.

127 William Bratton, Agency Theory and Incentive Compensation, in Research HandвоOK on Executive Pay 101104 (Randall S. Thomas \& Jennifer G. Hill eds., 2012); Mark J. Roe, Corporate Law's Limits, 31 J. Legal Stud. 233, 243-46 (2002).

128 Lucian A. Bebchuk, The Myth of Shareholder Franchise, 93 VA. L. Rev. 675, 715 (2007); Lynn A. Stout, The Unimportance of Being Efficient, 87 Mich. L. Rev. 613, 645-47 (1988).

129 Bebchuk, supra note 128, at 715; Barker, supra note 85, at 147.

130 Bebchuk, supra note 128, at 715-16.

131 Bebchuk, supra note 100, at 1467; Eisenberg, supra note 100, at 1489.

132 Eisenberg, supra note 100, at 1495-97. 
acquirers cannot punish them for weak results. ${ }^{133}$ In continental Europe, hostile takeovers are the exception due to typically concentrated stock ownership structures. ${ }^{134}$ The discipline of the capital market and the market for corporate control also depends on the efficiency of the capital market in absorbing and reflecting information, ${ }^{135}$ while the efficient capital market hypothesis has increasingly come under attack. ${ }^{136}$

Second, legal strategies are an insufficient remedy for the first agency problem as well. Specific rules and disclosure obligations may be good at preventing conflicts of interest in certain circumstances, or at reducing their impact, but it is impossible for the legislator to foresee and enforce every situation. Variable pay is often set in such a way that its connection with performance is tenuous (possibly because it is itself the result of an agency conflict ${ }^{137}$ ), which can even have perverse effects and induce excessive risk-taking. ${ }^{138}$ Even the effectiveness of well-designed variable remuneration is affected by other factors beyond the control of the company, such as the beneficiary's personal wealth. ${ }^{139}$ More fundamentally, there are certain types of agency costs that escape the reach of even the finest legal strategies. Legal provisions can successfully prevent directors and managers from "stealing", understood broadly as any transfer of value from shareholders to directors and managers, but can only indirectly tackle "shirking", i.e. poor decision-making that undermines shareholder value (and in many cases the latter is even protected by the business judgment rule). ${ }^{140}$ Finally, the said agency strategies are not always more transaction cost efficient than shareholder power. For example, when insurgents need to launch a hostile takeover just to replace directors, because the power of

133 Lucian A. Bевснuк et al., The Powerful Antitakeover Force of Staggered Boards: Theory, Evidence, and Policy, 54 Stan. L. Rev. 887, 912-14 (2002); Blanaid J. Clarke, Where was the 'Market for Corporate Control' When We Needed it?, in Corporate Governance and the Global Financial Crisis 75, 76-90 (W. Sun et al eds., 2011); Eisenberg, supra note 100, at 1497-99.

134 Davies \& Норт, supra note 11, at 270.

135 Clarke, supra note 133, at 76-90.

136 See Nicholas C. Barberis \& Richard Thaler, A Survey of Behavioral Finance, in Handbook of the Economics of Finance 1051, 1054-73 (2003); Andrei Shleifer, Inefficient Markets: An Introduction To Behavioral Finance (2000); Lynn A. Stout, The Mechanisms of Market Inefficiency: An Introduction to the New Finance, 28 J. Corp. L. 635, 653-54 (2003).

137 Bebchuk \& Fried, supra note 87.

138 William Sun ET AL., Introduction: Rethinking Corporate Governance - Lessons from the Global Financial Crisis, in Corporate Governance and the Global Financial Crisis 1, 7 (William Sun et al. eds., 2011).

139 John E. Core \& Wayne R. Guay, Is CEO Pay Too High and Are Incentives Too Low? A Wealth-Based Contracting Framework, 24 Acad. Mgmt. Persp. 5 (2010).

140 Roe, supra note 127, at 235. 
the shareholder meeting to do the latter by simple resolution is impaired. Incentive contracts based on results also come at a cost, as they shift part of the business risk to the beneficiary and force the company to compensate for this through higher pay. ${ }^{141}$ Another example is the presence of independent directors on the board. While this strategy may alleviate the first agency problem, it does not come without a price in terms of decision-making costs, as independent directors do not possess the same company-specific knowledge as inside board members. ${ }^{142}$

While the above may leave room for debate, one thing remains beyond doubt: the shareholder meeting cannot be abolished. Many of the mechanisms mentioned in fact presuppose certain powers of the shareholder meeting in order to function properly, such as the power to dismiss directors or to determine the success or failure of a takeover bid. Shareholder power, market discipline and legal strategies must be combined to counterbalance board authority. In the words of Arrow, board authority needs to be weighed against board accountability. ${ }^{143}$ But within the accountability techniques, where do we draw the line between the role of shareholder authority on the one hand and that of market discipline and legal strategies on the other hand?

This is where the criterion of inherent conflicts of interest comes into play again. When directors' interests are inherently opposed to those of the shareholders, market discipline and legal strategies (other than shareholder say) will lack the power required to induce directors to act against and completely disregard their own interests. Sanctions (either from markets or the law) will only cause the directors to internalize the negative external effects of their behavior and weigh them against their own interests. ${ }^{144}$ When the expected personal gains outweigh the expected punishment, the sanction will fail to obtain its intended effect. Directors should never consider their own interests against the interests of the company. Otherwise, the harm in terms of shareholder value may well exceed the gain from directors' specialization and other decision-making advantages.

141 Kathleen M. Eisenhardt, Agency Theory: An Assessment and Review, 14 Acad. Mgmt. Rev. 57, 61 (1989).

142 See Jeffrey N. Gordon, The Rise of Independent Director in the United States, 1950 2005: Of Shareholders Value and Stock Market Prices, 59 STAN. L. Rev. 1465, 1506 (2007).

143 Kenneth J. Arrow, The Limits of Organization (1974).

144 See M. Kruithof, Wanneer vormen tegenstrijdige belangen een belangenconflict?, in Van alle markten. Liber Amicorum Eddy Wymeersch 575, 584-90 (2008). 
2. Dysfunctional shareholders: shareholder passivity, short-termism, private interests, institutional investors and proxy advisors

Arguments invoked against extensive shareholder power are often based on shareholder passivity, short-termism, special interest shareholders and the weight of non-residual owners like institutional investors and proxy advisors. These are all variations on the same theme, namely that the shareholder meeting does not function properly, or, at the very least, that its optimal incentives are illusory.

Rationally apathetic shareholders throughout Europe do indeed stay away from shareholder meetings in great numbers ${ }^{145}$ and in the past have not engaged in intensive monitoring, at least during the times when the economy was strong. ${ }^{146}$ Some authors conclude that shareholder say should be limited, arguing that companies should not incur the high transaction costs of shareholder meetings when shareholders do not make use of their powers. ${ }^{147}$

A further consequence of shareholder absenteeism is that decisions are made by a small fraction of the shareholders, which can amplify the influence of large shareholders in a concentrated stock ownership structure (see Part III, Section 3) and the influence of minority shareholders in a dispersed ownership structure (or even board and management, but the latter can hardly be problematic in the eyes of a board primacist). When minority shareholders obtain decisive influence, the risk is real that the outcome of the vote in the shareholder meeting is determined by short-termism or private interests of minority shareholders. In particular, institutional investors like hedge funds have been accused of pressuring for actions that are profitable in the short run at the expense of long-term value. Shareholder myopia is regularly used as an argument to justify board insulation from shareholder intervention. ${ }^{148}$ In the aftermath of the global financial crisis of 2007-08, this criticism was

145 Luc Renneboog \& Peter Szilagyi, Shareholder Engagement at European General Meetings, in Boards and Shareholders in European Listed Companies 315, 320 (Massimo Belcredi \& Guido Ferrarini eds., 2013).

146 Barker, supra note 85, at 144-45.

147 Bainbridge, supra note 49, at 1751; Strine, supra note 74, at 1765; Christoph Van der Elst, Shareholder Activism in Belgium: The Belgian AGMs and EGMs in 2011, Tilburg Law School Legal Studies Research Paper Series No.002/2012, available at http:// ssrn.com/abstract $=1929792$.

148 E.g. Iman Anabtawi, Some Skepticism About Increasing Shareholder Power, 53 UCLA L. Rev. 561, 579-83 (2006); Martin Lipton, Takeover Bids in the Target's Boardroom, 35 Bus. Law. 101, 104-05, 114-16 (1979); Martin Lipton \& Paul K. Rowe, The Inconvenient Truth About Corporate Governance: Some Thoughts on Vice-Chancellor Strine's Essay, 33 J. CoRp. L. 63, 66-67 (2007); Lipton \& Savitt, supra note 49, at 745-47; Strine, supra note 74, at 1764, 1766-67. 
supplemented with shareholders' alleged tendency to support excessive risktaking (mainly in financial institutions). They would do so because they would reap all possible gains from risky decisions, while their possible losses are capped at the value of their investment due to shareholders' limited liability. ${ }^{149}$

Shareholders' interests can diverge from those of the company in many other ways. Shareholders with an additional role within the company (e.g. director, employee) or employee pension funds may vote against an efficient takeover only to protect current employment. ${ }^{150}$ Participants in the shareholder meeting may have fully uncoupled the economic risk from their voting power through share borrowing, short-selling or record date capture (empty voting) or may even have economic interests that are diametrically opposed to those of the company (negative voting). ${ }^{151}$ Shares are often also held by public pension funds, who may be subject to political pressure to defend local employment when plant closure is considered; ${ }^{152}$ faith-based organizations, pension funds, and socially responsible investor funds, who have an explicit social agenda; ${ }^{153}$ and sovereign wealth funds, which are sometimes suspected of favoring national interests. ${ }^{154}$ Because shareholders' interests are so heterogeneous and sometimes diverge from those of the company, board primacy champions contend that the board of directors should have primary decision-making authority to mediate the various interests of the shareholders, to protect shareholders from each other, and to give priority to the company's long-term interest. ${ }^{155}$

149 European Commission, Green Paper - Corporate governance in financial institutions and remuneration policies (COM(2010) 285 final), 4.

150 Anabtawi, supra note 148, at 586-90; Bainbridge, supra note 49, at 1754-55; Grant M. Hayden \& Matthew T. Bodie, One Share, One Vote and the False Promise of Shareholder Homogeneity, 30 CARDozo L. Rev. 445, 486-88 (2008).

151 Anabtawi, supra note 148, at 583-85; Carl Clottens, Empty Voting: A European Perspective, 9 ECFR 446, 447-51 (2012); Henry T. C. Hu \& Bernard Black, Empty Voting and Hidden (Morphable) Ownership: Taxonomy, Implications, and Reforms, 61 Bus. LAw. 1011 (2006).

152 Anabtawi, supra note 148, at 588-89; Bainbridge, supra note 49, at 1754-55; Roberta Romano, Less Is More: Making Institutional Investor Activism a Valuable Mechanism of Corporate Governance, 18 YALE J. Reg. 174, 231-32 (2001).

153 Lynn A. Stout, Takeovers in the Ivory Tower: How Academics Are Learning Martin Lipton May be Right, 60 Bus. Law. 1435, 1449 (2005).

154 Ronald J. Gilson \& Curtis J. Milhaupt, Sovereign Wealth Funds and Corporate Governance: A Minimalist Response to the New Mercantilism, 60 STAn. L. Rev. 1345 (2008); Hayden \& Bodie, supra note 150, at 488-91.

155 E.g. Anabtawi, supra note 148, at 564, 583-92; Bainbridge, supra note 49, at 1754; Martin Lipton, Twenty-Five Years After Takeover Bids in the Target's Boardroom: Old Battles, New Attacks and the Continuing War, Bus. Law. 1369, 1377-78 (2005); 
Institutional investors and proxy advisors, once hailed as the saviors of shareholder activism, also have different incentives than residual claimants, so that their role is sometimes invoked against shareholder empowerment. ${ }^{156}$ Bank trust departments, insurers and mutual funds regularly have other commercial relationships with the companies they are supposed to monitor (e.g. credit agreements, insurance coverage and management of private pension funds for these companies). ${ }^{157}$ In addition, the money managers effectively making the investment and monitoring decisions within the institutional investors may personally have even different incentives. ${ }^{158}$ Proxy advisory firms (and vote advisors) add another agency layer - they exercise noticeable influence over the votes in shareholder meetings, but their interests may diverge from those of the investors they advise. ${ }^{159}$ Again, these conflicts of interest are exacerbated when proxy advisors have other ties with the companies they monitor (e.g. when the latter is a client of the proxy advisor for corporate governance advice).

Advocates of strong shareholder power maintain that the fact that shareholders do not always make use of their decision-making power is not a reason to not at least allow them to make the decision. In the worst case, they argue, fewer value enhancing decisions will be made than desirable, which is still better than having none of these decisions at all. ${ }^{160}$ In response to the claims regarding private and short-term interests, they object that proposals from special interest shareholders and short-term oriented shareholders would not be able to garner a majority vote. ${ }^{161}$ One can indeed expect most of the problems of myopia and private interest to solve themselves in this way. This will not be the case, however, when a company is confronted with both absenteeism and private interests, because absenteeism can impart decisive influence on

Lipton \& Savitt, supra note 49, at 756-57; Lynn A. Stout, The Mythical Benefits of Shareholder Control, 93 VA. L. Rev. 789, 794 (2007).

156 Edward B. Rock, The Logic and (Uncertain) Significance of Institutional Shareholder Activism, 79 Geo. L.J. 445, 466-68 (1991); Strine, supra note 74, at 1764-65.

157 Bainbridge, supra note 49, at 1754; Rock, supra note 156, at 569-72.

158 Robert C. Clark, Four Stages of Capitalism: Reflections on Investment Management Treatises (Book Review), 94 Harv. L. Rev. 561, 564-66 (1981).

159 Tamara C. Belinfanti, The Proxy Advisory and Corporate Governance Industry: The Case for Increased Oversight and Control, Stan. J. L. Bus. \& Fin. 384, 387 (2009).

160 See, regarding institutional investors: Bebchuk, supra note 50, at 1799.

161 Bebchuk, supra note 59, at 883-84; Bebchuk, supra note 50, at 1799-1801; Bebchuk, supra note 128, at 721; George W. Dent, Jr., The Essential Unity of Shareholders and the Myth of Investor Short-Termism, 35 DeL. J. CoRp. L. 97, 106-09 (2010); Ronald J. Gilson \& Jeffrey N. Gordon, The Agency Costs of Agency Capitalism: Activist Investors and the Revaluation of Governance Rights, 113 Colum. L. Rev. 863, 897 (2013); Stewart J. Schwab \& Randall S. Thomas, Realigning Corporate Governance: Shareholder Activism by Labor Unions, 96 Мich. L. Rev. 1018, 1082-84 (1998). 
minority shareholders pursuing their private interests (majority requirements mostly being counted on the basis of votes present or represented). The problems of passivity, short-term thinking and private interests are real and certainly need to be dealt with. Although the means to do so go far beyond the scope of this article, the point I want to make here is that the solution is not to reduce shareholder power.

In a sound system of distribution of powers, a shift of powers from the shareholder meeting to the board of directors would not be the appropriate solution for private interests. Indeed, in the proposed framework the authority of the shareholder meeting is already limited to matters where directors face an inherent conflict of interest. Depriving the shareholder meeting of these powers because of a risk that some shareholders pursue private interests and shifting them to an inherently conflicted board of directors would only be throwing out the baby with the bath water - while getting rid of a few exceptional short-term or private interest inspired decisions of the shareholder meeting, one would also lose out, on a more permanent basis, on the benefit of having these specific decisions made by a corporate body that is at least not systematically conflicted. ${ }^{162}$ An example illustrates this point. Shareholders are frequently accused of short-term thinking when they have to choose between distributing a dividend and taking over another company. Shareholders, so it is said, will prefer the immediate gain of a dividend even if the takeover would create more value. Yet, we have seen above (Part II, Section 5) that both the dividend decision and the takeover are matters in which directors have an inherent conflict of interest. In contrast with the conflicts that may affect some shareholders, the conflict of the directors is systematic and affects all of them. Shifting the decision-making authority to the directors would thus create direct agency costs more frequently than short-termism in the shareholder meeting would. Because the powers of the shareholder meeting under the proposed framework include, among others, matters of discipline and accountability, such a shift would moreover produce pernicious indirect effects even on the exercise of powers that belonged in any case to the board of directors. ${ }^{163}$

Even without regard to the subject of the decision, one can easily see how directors are often guilty of the same failures for which shareholders face criticism. Directors, for instance, can just as well be considered empty voters. In the hypothesis where empty voting most commonly occurs, namely open companies with atomized share ownership, directors do not always own significant equity in the company (and, if they do, could secretly hedge their

162 See, with regard to amendments of articles of association generally, Bebchuk, supra note 50 , at $1803-04$.

163 See Lucian A. Bebchuk, The Myth That Insulating Boards Serves Long-Term Value, 113 Colum. L. Rev. 1637, 1679-81 (2013). 
participation). Similarly, short-termism also afflicts management and directors - their concern to preserve their position ought not to be conflated with a care for the long-term interest of the company and is often rather a source of conflicting interests. Directors may have a short-term horizon resulting from their wish to boast visible results during their tenure ${ }^{164}$ and from the fact that their claims on the corporation are limited to their tenure with the firm. ${ }^{165} \mathrm{In}$ addition, the market for corporate control, financial reporting obligations and variable remuneration may push them to keep share prices high in the short term, even if that will have a negative effect on long-term perspectives. ${ }^{166}$ Shareholder short-termism can, therefore, not support more autonomy of board and management. ${ }^{167}$ The same can be said with regard to shareholders' alleged risk seeking behavior. While shareholders enjoy limited liability, those who are able to tilt a vote in the general meeting do have a considerable investment at stake. For directors that is not generally the case. Admittedly, they have their job at stake but, as discussed above, this does not mean that their interests aligned with corporation. Moreover, their liability is tested only marginally and dismissal often takes place only in the most egregious cases. In the aftermath of the financial crisis, shareholders were accused of not monitoring directors risky behavior well enough. This can hardly be a reason for increasing the authority of those who took the risks.

\section{Tunneling by controlling shareholders}

The next question is if and how the second agency conflict affects the proposed framework. The second agency conflict refers to the tension between controlling shareholders and minority shareholders and, thus, plagues companies with concentrated stock ownership. ${ }^{168}$ Controlling shareholders risk appropriating private benefits of control, that they do not share with the minority, thus capturing $100 \%$ of the upside and bearing the related costs only in pro-

164 Mark J. Roe, Corporate Short-Termism - In the Boardroom and in the Courtroom, 68 Bus. LAw. (2013) 977, 996-98.

165 Michael C. Jensen, A Theory of the Firm: Governance, Residual Claims, and Organizational Forms 145 (2000).

166 Lucian A. Bebchuk \& Lars A. Stole, Do Short-Term Objectives Lead to Under- or Overinvestment in Long-Term Projects?, 48 J. Fin. 719-29 (1993); M.P. Narayanan, Managerial Incentives for Short-Term Results, 40 J. Fin. 1469-84 (1985); John R. Graham et al., The Economic Implications of Corporate Financial Reporting, 40 J. Aсcт. \& Econ. 3-73 (2005); Jeremy C. Stein, Takeover Threats and Managerial Myopia, 96 J. Pol. Econ. 61 (1988); Jeremy C. Stein, Efficient Capital Markets, Inefficient Firms: A Model of Myopic Corporate Behavior, Q. J. Econ. 655 (1989).

167 Roe, supra note 164, at 1003.

168 Armour et al., supra note 67, at 36 
portion to its stockholding, externalizing the rest of the costs on the minority ${ }^{169}$. The second agency problem grows exponentially when the majority shareholder boosts his influence by means of so-called control enhancing mechanisms (or controlling minority structures), such as shares with multiple voting rights, pyramid structures and cross-holdings of shares. ${ }^{170}$ An intuitive reflex to the controlling shareholder's preponderance in the shareholder meeting could be to transfer authority to the board of directors.

As a rule, increasing board power in response to the second agency problem will not be of much avail because the board of directors is usually dominated by directors appointed by the controlling shareholder. One could attempt to solve this by also curbing the shareholders' meeting appointment and dismissal rights. That would increase directors' clout on their own appointment and removal, which can hardly be in the interest of the company, given directors' inherent conflict of interest on this point. In addition, it would reduce the accountability of the board and, thus, merely replace the second agency conflict with the first. In dual board structures the reasoning is slightly different. Directors of supervisory boards do not face an inherent conflict of interest with regard to the election and removal of executive board members. One could, therefore, contemplate reducing shareholders' voice on the election of executive board members in favor of the supervisory board, something that is indeed common in two-tier boards. ${ }^{171}$ The small increase in first agency costs (shareholder control is indeed not limited, but becomes more indirect) may still be a reasonable price to pay for the reduction of the second agency conflict. However, for substantive powers, executive board members usually have the same inherent conflicts of interest as members of a monistic board - they are still directors, after all, and thus subject to conflicts inherent in a directorship. Theoretically, if the shareholder meeting would have no influence over the position of executive directors (which is virtually never the case ${ }^{172}$ ), one could make a case for increasing the authority of the executive board on matters where the conflict relates to their position, such as takeover defenses, mergers etc. However, personal side benefits in negotiations might remain an important source of conflict. This is not an argument against dual board structures an sich, but it does lead to the conclusion that dual board structures

169 See Alexander Dyck \& Luigi Zingales, Private Benefits of Control: An International Comparison, 59 J. Fin. 537 (2004); Simon Johnson et al., Tunneling, 90 Am. Econ. Rev. 22 (2000), reprinted in Capital Markets and Company Law (Klaus Hopt \& Eddy Wymeersch eds., 2003).

170 Lucian A. Bebchuk et al., Stock Pyramids, Cross-Ownership, and Dual Class Equity, in Concentrated Corporate Ownership 295, 301-06 (Randall K. Morck ed., 2000).

171 Cools, supra note 3, at 209-17. See however the text accompanying next footnote.

172 Cools, supra note 3, at 209-17. 
are not a convincing reason to deprive shareholder meeting of substantive powers that it would have in the proposed framework.

Varying the legal distribution of powers with stock ownership patterns (irrespective of board structure) would also create practical difficulties. A statutory rule that distinguishes along these lines, if it could at all be formulated adequately, would continuously impose complex calculations on the company as we know them in the context of mandatory takeover bids. ${ }^{173}$ Even more intricate issues arise when one considers the indirect effects such an ownership dependent power shift could possibly produce. Elsewhere I have explained how expansive shareholder power likely contributes to concentrated stock ownership and how strong board autonomy may be a reason for controllers to sell off their stock and let it disperse. ${ }^{174}$ If stock ownership structures respond to the legal distribution of powers, then the law should not adapt the distribution of powers to ownership structures in the other direction, as this risks creating instability. Specifically, if the law responded to ownership concentration by scaling down shareholder power, ownership would disperse again, which would then cause the shareholder-friendly regime to apply again, causing ownership to concentrate again, thus creating an endless cycle of concentration and dispersal, with changing legal regimes.

Again, the conclusion is that the second agency conflict does not call for tweaks in the legal distribution of powers between the board and the shareholder meeting. Strategies specifically designed to protect minority shareholders, such as techniques for proportional representation on the board, special procedures for conflict of interest situations (including related party transactions), limitations on control enhancing mechanisms, liability and avoidance rules on abuse of majority and carefully designed enhanced majority requirements, seem more apt to come to grips with the second agency conflict. ${ }^{175}$

173 The difference is obviously that in the context of the mandatory bid, the calculation has to be made only by important shareholders at times their equity stake changes, while in the context of distribution of powers a public company would have to make the calculation almost every time a decision is made.

174 Sofie Cools, The Real Difference in Corporate Law Between the United States and Continental Europe: Distribution of Powers, 30 DEL. J. CoRp. L. 697, 755-62 (2005); Sofie Cools, La répartition juridique des pouvoirs au sein des sociétés d'Europe continentale et des sociétés américaines, 106 Rev. Prat. Soc. 149, 179-92 (2007).

175 See EnRiques et al., supra note 73, at 89-99; Pierre-Henri Conac et al., Constraining Dominant Shareholders' Self-Dealing: The Legal Framework in France, Germany, and Italy, 4 ECFR 491 (2007). 


\section{Stakebolder interests}

So far this article proceeded on the assumption that corporate interests equal long-term shareholder value. While many authors, especially in the United States, have proclaimed shareholder wealth maximization the norm for corporate governance, ${ }^{176}$ this is far from uncontested. Others believe that a company should maximize the interests of all constituents impacted by the company's actions, including not only shareholders but also employees, suppliers, creditors, and even the broader community. ${ }^{177}$ Adherents of the shareholder value norm often try to find middle ground in the position that corporate law should indeed strive to maximize value for all constituents, but that this goal is best attained through shareholder wealth maximization, as this would increase the total pie which can be divided among all constituents. ${ }^{178}$ The goal here is not to take sides in this debate, ${ }^{179}$ but to investigate the implications of possible stakeholder concerns for the distribution of powers between the shareholder meeting and the board of directors in the proposed framework.

Stakeholder concerns are only seldom addressed by granting stakeholders a direct say in corporate decision-making, other than the appointment of directors (and thus indirect participation). ${ }^{180}$ The textbook example of this ap-

176 J. Armour et al., What is Corporate Law?, in The Anatomy of Corporate Law 1, 28-29 (R. Kraakman et al. eds., 2nd ed. 2009); Bainbridge, supra note 48, at 573; Stephen M. Bainbridge, In Defense of the Shareholder Wealth Maximization Norm: A Reply to Professor Green, 50 Wash. \& LeE L. Rev. 1423, 1423-25 (1993); Stephen M. Bainbridge, Director v. Shareholder Primacy in the Convergence Debate, 16 Transnat'l Law. 45, 47 (2002); Robert C. Clark, Corporate Law 678 (1986); Jill E. Fisch, Measuring Efficiency in Corporate Law: The Role of Shareholder Primacy, 31 J. Corp. L. 637, 646 (2006); Henry Hansmann \& Reinier Kraakman, The End of History in Corporate Law, 89 Geo. L.J. 439 (2001); Michael C. Jensen, Value Maximization, Stakeholder Theory and the Corporate Objective Function, 14 J. AppL. CORP. Fin. 8 (2001).

177 E. Merrick Dodd, Jr., For Whom Are Corporate Managers Trustees?, 45 Harv. L. Rev. 1145, 1147-48 (1932); Keay, supra note 78, at 374; Beate Sjafjell, The Golden Mean or a Dead End? The Takeover Directive in a Shareholder versus Stakeholder Perspective, in European Company Law in Accelerated Progress 107, 109-10 (Steef M. Bartman ed., 2006); Margaret M. Blair \& Lynn A. Stout, Specific Investment and Corporate Law, Eur. Bus. Org. L. Rev. 473 (2006).

178 Armour et al., supra note 176, at 28-29; Jean-Pierre Bertrel, Liberté contractuelle et sociétés, Rev. TRIm. Dr. Comm. 595, 625-26, 628 (1996); Hansmann \& Kraakman, supra note 175, at 441-42; Virginia E. Harper Ho, 'Enlightened Shareholder Value': Corporate Governance Beyond the Shareholder-Stakeholder Divide, 36 J. CoRP. L. 59 (2010); Keay, supra note 78, at 376.

179 This relates to the third agency conflict, which concerns the relationship between the company and its contractual counterparties (ARMOUR et al., supra note 67, at 36).

180 Eisenberg, supra note 58, at 17-21; EnRIQues et al, supra note 73, at 101. 
proach is the German Mittbestimmung, where employee representatives sit on the supervisory board. In case of participation of stakeholders in decisionmaking, it is unnecessary to decide whether the board or the shareholder meeting is in a best position to defend stakeholder interests. The only reason to adapt the distribution of powers would then be to limit or to expand scope of stakeholder say, in which case a new delicate balance must be struck between agency and transaction costs, taking into account not only the reasoning made above but also the benefits of more or less stakeholder say.

Another way to promote stakeholder value is by obliging (or at least allowing) the company organs to take into account or to further stakeholder interests. ${ }^{181}$ This is where the distribution of powers debate flares up. Board primacists often assert that the board and management are in a better position than the shareholder meeting to take into account stakeholder interests - an argument that has been raised particularly in the debate on takeover defenses. ${ }^{182}$ The protection of stakeholder interests would in their opinion legitimize more managerial and board discretion. As mentioned in Part I, Section 2, some ${ }^{183}$ board primacists go a step further and view the board as a mediator, balancing the various interests of shareholders and corporate constituents. ${ }^{184}$ Corporate power should for that reason remain in the hands of managers. Too much shareholder power could allow shareholders to opportunistically "hold up" other team members, i.e. make unreasonable requests (e.g. for the payment of a generous dividend while cutting down on employee benefits) knowing that stakeholders who have made firm-specific investments cannot leave easily. ${ }^{185}$

The first reason for the board's alleged suitability to protect stakeholder interests is that the board would have similar interests as a consequence of their natural tendency to preserve their own employment. In a takeover, for example, this would make directors more inclined to pay heed to local employment. ${ }^{186} \mathrm{~A}$ serious problem with this argument is that the overlap of interests of directors and stakeholders is completely random. Directors' interests might just as well diametrically oppose those of stakeholders: they may refuse to sell the company to a buyer that would improve the employees' prospects while displacing current management or they may agree with a merger that will be followed by layoffs because the directors were seduced with handsome

181 EnRiQues et al, supra note 73, at 103.

182 E.g. John C. Coffee, Jr., The Uncertain Case for Takeover Reform: An Essay on Stockholders, Stakeholders and Bust-Ups, 1988 Wis. L. Rev. 435, 449.

183 Not all board primacists agree with the conception of the board as a mediator. See e.g. Bainbridge, supra note 48 , at 593-605.

184 Blair \& Stout, supra note 54, at 253-54, 286, 304-05.

185 Stout, supra note 155 , at 795-96.

186 Stout, supra note 155, at 797. 
perks. ${ }^{187}$ In fact, the same finding of random alignment of interests was made above with regard to some shareholders and there the private interests were invoked by board primacists as argument against shareholder power (Part III, Section 2). The stakeholder argument could, therefore, be turned around and be used to support more shareholder say, on the basis that at least some shareholders will use their increased power to advance stakeholders' concerns. ${ }^{188}$ Because of the randomness of this alignment, ${ }^{189} \mathrm{I}$ do not subscribe to such an argument either.

A second reason why directors would be better advocates of stakeholder interests is that in most jurisdictions they have a legal duty of loyalty. ${ }^{190} \mathrm{In}$ the context of stakeholder protection, this duty might not, however, be of much comfort, as it is extremely difficult for courts to review compliance. ${ }^{191}$ Different constituents often have conflicting interests and even interests of the same category of stakeholders may diverge depending on the time horizon over which they are considered. ${ }^{192}$ The selection of "valuable" stakeholder interests that enhance the overall welfare (or however one would name the goal) and the exclusion of those that have just been referred to as private interests is a thorny matter. As a consequence, one could "justify almost any action on the grounds that it benefits some group" ${ }^{193}$ Allowing or mandating directors to take into account stakeholder interests would in the first place broaden their margin of discretion and would be prone to abuse. ${ }^{194}$ Because of their own inherent interests, directors cannot be considered a neutral mediator.

Because there is nothing that ties directors' interests to those of the stakeholders on a systematic basis, stakeholder interests cannot justify a shift of powers between directors and shareholders in whatever direction. ${ }^{195}$ There is

187 Bebchuk, supra note 59, at 911.

188 See e.g. Lisa M. Fairfax, Making the Corporation Safe for Shareholder Democracy, 69 Оніо Sт. L.J. 53, 83-85 (2008); Lisa M. Fairfax, Shareholder Democracy on Trial, 3 VA. L. \& Bus. Rev. 1, 31-32 (2008).

189 See the difficulties raised in Part II, Section 2 and Fairfax, supra note 188, at 94-96 (some groups of stakeholders, mainly creditors, do not benefit from shareholder democracy).

190 Stout, supra note 155, at 797.

191 Bebchuk, supra note 59, at 910.

192 See Hansmann, supra note 76, at 44.

193 Oliver Hart, An Economist's View of Fiduciary Duty, 43 U. Toronto L.J. 299, 303 (1993).

194 Bebchuk, supra note 75, at 1021-1027; EnRIQues et al, supra note 73, at 103.

195 A different kind of relationship might exist in that large shareholder influence could call for more stakeholder protection (see Martin Gelter, The Dark Side of Shareholder Influence: Managerial Autonomy and Stakeholder Orientation in Comparative Corporate Governance, 50 HARv. INT'L L. J. 129 (2009)). 
one big exception. The proposed framework is valid only for enterprises in going concern. When continuity is endangered, the incentives of shareholders as residual owners disappear. Once their investment is lost, shareholders have an interest in taking excessive risk - further losses are, in any case, externalized to creditors who otherwise might still recoup some money, while any unexpected profits would still be reaped by the shareholders. In this situation, the residual claimants are no longer the shareholders but the creditors and the latter become better fit to make decisions for the company. ${ }^{196}$

\section{Conclusion}

Shareholder franchise has been at the forefront of corporate governance reform and debates for a few decades now. Still, how the scope of their franchise should be demarcated remained unclear. This article searched for an efficient and consistent criterion and, after weighing all arguments pro and contra shareholder power, found it in directors' inherent conflicts of interest. Shareholder say should comprise, but also be limited to, those matters in which directors face conflicting interests purely because of their position of director (in some cases only when the decision is material for the company). Assigning shareholders more powers causes unnecessary costs of organizing shareholder meetings and threatens to lead to poor decision-making and avoidable influence of special interest shareholders. Giving shareholders fewer powers may engender unacceptably high agency costs within the board of directors.

In the present day, conflicts of interest make headlines worldwide in all areas of law. The global financial crisis has sparked outrage about conflicts of interest in financial institutions providing multiple services, in rating agencies, in experts publishing investment recommendations etc. Corporate lawmakers should, in this context, not lose sight of an inherent conflict of interest within corporations that was already an explicit concern over two hundred years ago. 